\title{
Resignation threats add steel to French revolt
}

Declan Butler, Paris

Axel Kahn's is one of the most wellheeled genetics labs in France. As a pillar of the research establishment, he is not given to tempestuous announcements. But earlier this month, he threatened to resign as director of the Cochin Institute in Paris unless the government takes immediate and significant steps to boost French research.

Kahn, together with many of the country's top scientists, is a prominent member of a researchers' revolt. The protesters, known as the Save Research movement, made their demands on 7 January in an online petition. Theywant the government to pay research agencies the millions of euros it owes them, to boost recruitment of young scientists, and to launch a national debate on science. To give teeth to their demands, signatories pledge to resign all administrative duties, an act that could bring the country's research system to its knees.

The seeds of revolt were sown last year, when the national research agencies bore the brunt of a $1.3 \%$ cut in the country's $€ 8.8$ billion (US\$10-billion) research budget. At Kahn's laboratory, for example, public funding fell $10 \%$, and staff numbers dropped by

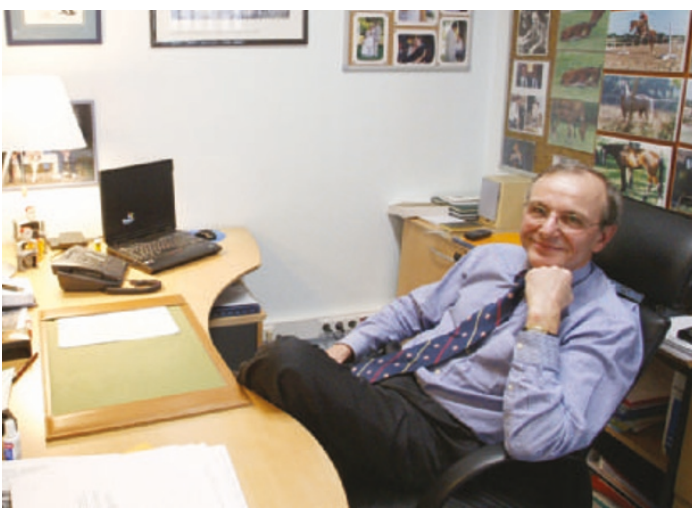

Axel Kahn, director of the Cochin Institute, says he will resign as part of a protest by French scientists.

15 to around 150. "And we are one of the top labs in France," he says. "Just imagine the situation elsewhere."

Faced with crushing public deficits, the finance ministry has also withheld millions from the agencies, bringing them close to bankruptcy. The CNRS, France's national research agency, was until last week owed $€ 172$ million. The agency was only able to avoid going broke after the government freed up $€ 103$ million, promising to repay the rest in 2005.
But it is the job situation that sparked the protests. At INSERM, the national biomedical research agency, staff numbers are being cut and only 30 new positions are available this year, compared with 90 in 2003. New three- to five-year contracts, paying $€ 1,900$ a month, are also being shunned by young scientists, as it is almost impossible to rent an apartment or get a loan on a short-term contract.

Kahn says that anger among $\mathrm{PhD}$ students infected more senior staff, leading them to establish the petition, which has attracted more than 17,000 signatures. As a well-known public figure, Kahn feels obliged to go one step further than other signatories and resign his research position. He seems to be deadly serious about carrying this through: "I can't allow myself to make threats that are not credible."

Last weekend, science minister Claudie Haigneré received Alain Trautmann, co-head of the biology department at the Cochin Institute and spokesman for the Save Research movement. Haigneré described the meeting as "constructive" and promised an interministerial meeting to discuss the demands. http://recherche-en-danger.apinc.org

\section{Europe's researchers up in arms over clinical-trial rules}

\section{Alison Abbott}

Some 2,000 clinical researchers have signed an Internet petition calling for changes to proposed new European Union (EU) rules on patient trials. They say that, as the revised rules stand, they would place immense bureaucratic burdens on their backs.

Under the new rules, researchers who conduct clinical trials would have to fill out mountains of forms, follow and report the well-being of patients to a central database, and accept full liability for trials whose responsibility was previously shared among different authorities.

The researchers admit that they have woken up late to the problems posed by the 2001 EU Directive on Clinical Trials, which is due to be implemented through national laws by this May. But they are hopeful that its impact will be curtailed by a more detailed, follow-up directive now being drafted in Brussels, and through the discretion of national governments in passing the laws.

The directive was originally drawn up in the Enterprise Directorate of the European Commission to harmonize the regulation of large clinical trials conducted by the drug industry. But as it developed, its remit was extended to cover all patient trials, including smaller ones conducted by academics involving drugs already on the market.

"All along, there has been too little consultation with those affected by the rules," says Brian Moulton, a pharmacologist at the Dublin-based Irish Clinical Oncology Research Group, which helped to organize the petition. "But we hope that the extraordinary level of support for our petition will influence policy-makers."

The directive requires clinical researchers to conform with two detailed sets of EU guidelines, called Good Manufacturing Practice and Good Clinical Practice, and to follow new procedures designed to control the large-scale clinical trials undertaken by drug companies. Scientists hope to relax these obligations by influencing the contents of a subsidiary set of rules on clinical research being drawn up by the commission.

A spokeswoman for the commission says that it is now sensitive to academics' concerns, which have been supported by research commissioner Philippe Busquin. Commission officials are in "internal debates about the extent to which academic research should be tied to the main directive", she says.

Critics say that, unless the guidelines are worded appropriately, trials that the drug industry doesn't want to run could be endangered because academics could no longer afford to do them. Such trials include efficacy comparisons of drugs that are already in widespread use, and tests of procedures using surgery or medical devices.

Peter Boyle, director of the International Agency for Research on Cancer in Lyon, France, cites a recent 20-year cancer study as a potential victim of the rules. The Milan-based European Institute of Oncology's comparison of radical mastectomy against radical lumpectomy for breast cancer, he points out, "showed no difference in outcome between the procedures, so it had a huge impact for millions of women - but it's not likely that it could be done under the new rules because the administration costs would be too high."

But the problem doesn't just relate to cost. Jane Armitage, a clinician at the University of Oxford's Clinical Trial Service Unit, UK, says that under the new rules, many trials that academics do now could not take place, because only drugs explicitly labelled for use in a trial could be used. "Many trials are based on doctors recommending patients to takeor avoid - aspirin, or other drugs that they do not provide themselves," she says. www.saveeuropeanresearch.org 